Are complex innovators more persistent than single innovators? An empirical analysis of innovation persistence drivers

Christian Le Bas, Nicolas Poussing 


\section{GATE Groupe d'Analyse et de Théorie Économique Lyon-St Étienne}

93, chemin des Mouilles 69130 Ecully - France

Tel. +33 (0)4 72866060

Fax $+33(0) 472866090$

6, rue Basse des Rives 42023 Saint-Etienne cedex 02 - France

Tel. +33 (0)4 77421960

Fax. $+33(0) 477421950$

Messagerie électronique / Email : gate@gate.cnrs.fr

Téléchargement / Download : http://www.gate.cnrs.fr - Publications / Working Papers 


\title{
Are complex innovators more persistent than single innovators? An empirical analysis of innovation persistence drivers ${ }^{1}$
}

Christian Le Bas, Professor, Université de Lyon, Lyon, F-69007, France ; CNRS, GATE Lyon Saint-Etienne, Ecully, F-69130, France. Université Lyon 2, Lyon, F-69007, France. christian.lebas@univ-lyon2.fr

Nicolas Poussing, Research Fellow, CEPS/INSTEAD, 3, Avenue de la Fonte, 4364 Esch-surAlzette, Luxembourg; email: nicolas.poussing@ ceps.lu

\begin{abstract}
This paper examines the persistence of innovation behaviour at the firm level (manufacturing and services sectors). We attempt to answer the question: does being successful in past innovation activities increase the probability of being successful in current innovation activities? We contribute to the literature by explicitly distinguishing between single and complex innovation strategies. Using two waves of the Community Innovation Survey (2002-2004, 2006-2008) conducted in Luxembourg, the regressions show that complex innovators are more inclined to remain persistent innovators than single innovators. Within the group of single innovators pure product innovators have an advantage over pure process innovators. The results support the idea that the differences in innovation strategies across firms are important for understanding the firm innovation dynamics.
\end{abstract}

Keywords: Innovation; Persistence; Single and Complex Innovators, CIS

Résumé. Cet article étudie le comportement de persistance à l'innovation des firmes (des secteurs de l'industrie et des services). Nous répondons à la question: est ce que les firmes qui ont innové au cours d'une période de temps ont une probabilité d'innover encore la période suivante accrue ? Notre contribution à la littérature réside dans la fait que nous distinguons explicitement les innovateurs simples (innovant en produit ou en procédé) et complexes (innovant en produit et en procédé). On utilise deux vagues d'enquêtes communautaires Innovation (2002-2004, 2006-2008) conduites au Luxembourg. Les régressions montrent que les innovateurs complexes sont plus enclins à rester persistants innovateurs que les innovateurs simples. Au sein du groupe des innovateurs simples les innovateurs en produit ont un avantage sur les innovateurs en procédé. Ces résultats confortent l'idée que les différences dans les stratégies d'innovation entre firmes sont importantes pour comprendre leurs dynamiques d'innovation.

Mots clés : Keywords: Innovation; Persistance; Innovateur simple et complexe, CIS

\footnotetext{
${ }^{1}$ Financial support from Region Rhône-Alpes (Cluster GOSPI) is gratefully acknowledged. Christian Le Bas also wishes to thank CEPS/Instead for its support.
} 


\section{Introduction}

This paper considers the factors that determine the process of persistent innovation at the firm level. With respect to the current literature dealing with the drivers of persistence in technological innovation we develop a new perspective by distinguishing in an explicit way between two types of innovators: complex and single innovators. The former innovators carry out product and process innovation in the same time period; the latter only one of the two types. The reasons for studying carefully the temporal process of innovation of complex innovators are the following. Prior studies by Henderson and Cockburn (1998) and Hill and Rothaermel (2003) have indicated that in knowledge-intensive industries firms' adaptation to rapidly changing environments frequently necessitates both product and process innovation ${ }^{2}$. Cefis and Marsili (2005) showed for a sample of Dutch enterprises that firms that introduce both product and process innovations benefit from a premium in survival. As a consequence we can hypothesize that complex innovators are more inclined to remain persistent innovators than single innovators. However, the literature is not unanimous. For instance, Antonelli, Crespi and Scellato (2012) considered a class of innovators (general innovators) that undertake product, process and organization innovation and showed that they are not persistent. Our own category of complex innovators is a little different since organization is not included in our definition.

Because of the existence of conflict among a few studies found in the literature as far as complex innovator behaviour is concerned, it appears important to reexamine the issue of whether one type of innovator (complex, single) is more persistent than the other.

Our work could contribute to the (not too large) literature dealing with persistence in innovation from three empirical perspectives: 1) we put some emphasis on particular types of innovators, 2) we study the topic of persistence through the different types of innovation as they are referenced by the two waves of innovation surveys and 3) we analyse, albeit briefly, the role of organizational innovation as a factor supporting persistent innovation behaviour.

The paper is organized as follows. In section 1 we offer a survey of the literature and set out our research question. In the next section the data are delineated (section 2). Then the

\footnotetext{
2 Polder et al. (2009) find there is complementarity between product and process innovations in Netherland manufacturing.
} 
empirical models and variables are defined (section 3). Section 4 is dedicated to the estimations and results. Finally we discuss our findings and conclude.

\section{Survey of the literature and research question}

Three complementary kinds of explanations have been put forth to account for innovation persistence at the firm level. First is the hypothesis of knowledge accumulation. It stipulates that experience in innovation is associated with dynamic increasing returns in the form of learning-by-doing and learning-to-learn effects, which enhance knowledge stocks and the probability of future innovations. It suggests a combination of 'learning effects' in the production of innovation and positive feedback between the accumulation of knowledge and the production of innovation. In other words, the production of innovation would be strongly subject to dynamic economies of scale (Duguet and Monjon, 2002; Geroski, Van Reenen and Walters, 1997; Latham and Le Bas, 2006). This hypothesis looks like the well-known view that R\&D has two faces: innovation and learning (Cohen and Levinthal, 1989). Learning here is the capacity to innovate later. There are many views of the way in which learning-by-doing works in research activity. By innovating the firm explores a process of learning and can discover new ideas by recombining (rearranging) old ones. The more it has produced pieces of knowledge in the past, the more it could recombine them in order to produce new pieces of knowledge (such a process is considered by Weitzman, 1996). In the literature this hypothesis is also acknowledged as 'past innovation affects current innovation' (Duguet and Monjon, 2002; Geroski, Van Reenen and Walters, 1997). The 'success breeds success' hypothesis argues that a firm can gain locked-in advantages over other firms due to successful innovations. This hypothesis holds in a few words: innovation feeds profitability, which funds innovation activities a time period later. The main difference between the two explanatory frames is that, here, the economic and commercial successes play a role. The third is labelled 'sunk costs in R\&D activities'. Antonelli, Crespi and Scellato (2012) interpret the evidence of persistence in innovation efforts as intertemporal stability in the undertaking of R\&D efforts. Indeed, the firm always faces the choice between investing or not investing in R\&D activities, a form of investment that has specific characteristics: the notion of 'sunk costs' effects refers to the continuity of the $R \& D$ expenditures. A firm deciding to engage in $R \& D$ activities has to incur start-up costs that are usually not recoverable. These sunk costs represent a barrier to both entry to and exit from $R \& D$ activity. The presence of important sunk costs represents an 
essential motive for entering and staying in a specific regime of R\&D activity. It shows that persistence in innovative activity sets up a complex path-dependent process. ${ }^{3}$

We turn now to the main empirical findings produced by the literature.

1. There is no consensus regarding the 'scale' of persistence in innovation. Duguet and Monjon (2002) concluded that it is strong; by contrast Geroski, Van Reenen and Walters (1997) argued that few firms innovate persistently (an outcome shared by Malerba and Orsenigo, 1999). Until recently the topic has still been controversial. For instance, Raymond et al. (2006), using firm data from three waves of the Community Innovation Surveys for Dutch manufacturing (from 1994 to 2000), found that there is no evidence of true persistence in achieving technological product or process innovations, while by contrast Antonelli, Crespi and Scellato (2012), with a sample of 451 Italian manufacturing companies observed during the years 1998-2006, confirmed the presence of significant persistence in innovation. The other studies retain a more balanced view. Among others one reason for these divergent points of view is that the studies use different definitions of innovation and different indicators for different countries and time periods.

2. Firm size is an important determinant of innovative activity size (Athrye and Edwards, 2003). In fact, a minimum threshold size for total revenues (turnover) appears to be required for the firm to be able to fund permanent (persistent) $R \& D$ activity and to have the possibility of innovating as well. Conducting permanent $R \& D$ activity is a means to produce new ideas continuously (Antonelli, Crespi and Scellato, 2012; Duguet and Monjon, 2002). However, this relationship between innovative persistence is certainly not linear (Pavitt, Robson and Townsend, 1987) and does not take the same form in all industrial sectors. This may explain why the innovation spell length is better explained by the number of patents at the beginning of the spell as a proxy for the size of innovative activity (Geroski, Van Reenen and Walters, 1997; Le Bas, Cabagnols and Gay, 2003). This explains why small patentees patent in a short period

\footnotetext{
${ }^{3}$ As noted by Colombelli and von Tunzelmann (2011), 'positive feedback is an essential concept in order to capture the role of local attractors in complexity. The trajectory of dynamical systems is attracted towards an attractor through positive feedback occurring over time. Positive feedbacks exacerbate initial stresses in the system, so rendering it unable to absorb shocks and re-establishing the original equilibrium. Very strong interactions occur between the parts of a system and there is an absence of a central hierarchical structure able to 'govern' outcomes. Positive feedbacks occur when a change tendency is reinforced rather than dampened down as occurs with the negative feedback and hence engender out of equilibrium conditions.'
} 
of time, and why heavy (consistent) patentees are persistent innovators. In other words there is strong evidence stating that only consistent innovators become persistent innovators (see Malerba and Orsenigo, 1999). From this point of view it is damaging to use CIS surveys that exclude small-sized firms (fewer than 10 persons).

3. The size of innovative activity influences the degree of technological variety (Le Bas, Cabagnols and Gay, 2003). It may be that the firm size still plays a role here because it affects the size of innovative activity as well.

4. The type of industry matters (in relation to the French industry see Lhuillery, 1994). In high-tech industries the scale of innovative persistence is higher than in low-tech industries (in particular, Duguet and Monjon, 2002; see also Geroski, Van Reenen and Walters, 1997; Le Bas, Cabagnols and Gay, 2003). Similarly mature industries have more persistence in innovation than new industries. Recently Raymond et al. (2010) confirmed this evidence.

5. There is a strong relationship between persistence in innovative behaviour and persistence of above average profits. For instance, Cefis (1990) suggested that firms that are systematic innovators earn profits above the average and have a strong incentive to keep innovating and earning profits above the average. Cefis and Ciccarelli (2005), with a panel of 267 UK manufacturing firms over the period 19881992, found a difference in profitability between innovators and non-innovators, which is greater when the comparison is between persistent innovators and noninnovators. The links between innovative persistence and economic performance have been studied by Le Bas and Négassi (2002). They showed that persistence has a positive impact on sectoral performance.

6. The firm population of sporadic innovators is low but not null (Duguet and Monjon, 2002; Geroski, Van Reenen and Walters, 1997; Le Bas, Cabagnols and Gay, 2003). This fact requires more attention. By contrast a large fraction of innovators are occasional (Malerba, Orsenigo and Peretto, 1997). In the same spirit Malerba and Orsenigo (1999) showed that a large proportion of new innovators cease to innovate soon after entry into the industry. 
To assess the occurrence of innovation persistence the type of innovation (process versus product) is important (Lhuillery, 1994). ${ }^{4}$ However, until now this assumption has not been dealt with as much in the literature. Roper and Hewitt-Dundas (2008) found differences as far as the determinants of the type of innovation are concerned: with product innovation persistence is linked more strongly to strategic factors and process changes are more often driven by market pressures. Antonelli, Crespi and Scellato (2012) obtained a relatively higher persistence level for product innovation than for process innovation. By contrast, to our knowledge, few studies have dealt with complex innovators, that is to say firms that implement both new products and new processes. One exception is the paper by Antonelli, Crespi and Scellato (2012), which suggested that when a firm undertakes different types of innovation jointly (i.e. product, process and organizational innovation), a lower degree of state dependence is expected. To put it simply, according to their study 'general' innovators are less persistent. Some papers have distinguished whether the firm is a single persistent innovator in products or in processes. For instance, Haned (2011) found that the coefficients of the lagged dependent variable accounting for the frequency of past innovations is stronger and more significant for product innovators than for process innovators, and thus that the trend for persistence is larger for product innovators than for process innovators. These results are in line with those by Clausen et al. (2010) and Roper and Hewitt-Dundas (2008).

For the clarity of our analysis we define pure product innovators as firms that invest in innovative activities to implement only new products and pure process innovators as firms that implement new processes. These two types of firms will be considered as single innovators. Conversely the firms that implement both types of innovations in the same time period will be defined as complex innovators. It must be noted that only a few studies have dealt with the economic implications of single and complex innovator strategies. ${ }^{5}$ In this article, we contribute to the literature on innovation persistence by analysing the differences in innovation strategies across firms. In more specific terms our research aims to establish

\footnotetext{
${ }^{4}$ Lhuillery (1994) remarked that radical innovators are persistent.

5 Cesaratto, Mangano and Massini (1995) defined a category of 'complex innovators' that concerns enterprises from the 'suppliers of traditional intermediate goods' sector and the 'specialized suppliers of intermediate goods and equipment' sector. Wood (1997) carried out a cluster analysis of a specially constructed database of UK firms. He found six clusters of firms: cluster 1 encompasses firms that introduce both a novel product and a novel process innovation, in cluster 2 the firms reported only product innovation, in cluster 3 firms are likely to have introduced a novel process innovation and in the last clusters the firms have a low probability of innovating. His taxonomy gives more consistency to our approach to firm innovation strategy based on the 'single versus complex' choice.
} 
whether complex innovators are more persistent as innovators than single innovators. Indeed our approach aiming to study the differences in innovation strategies across firms as a factor driving innovation persistence is in line with the recent paper by Clausen et al. (2010) on the Norwegian case.

The rich frame of CIS enables us to study not only whether firms innovate over time but also the type of innovation implemented, making it possible to analyse the trends of innovation persistence for a particular type of innovation. ${ }^{6}$

\section{Data}

In this paper we use data sourced by two different CISs (Community Innovation Surveys) carried out in Luxembourg by CEPS/INSTEAD in collaboration with STATEC: CIS 2004 and CIS 2008. CIS 2004 covers the time period 2002 to 2004, while CIS 2008 covers the period 2006 to 2008. While there is a one-year time period missing (2005), the two surveys set up precious tools for following firm innovation activity over time, in particular for checking which firms are persistently innovative and accounting for the factors that drive persistent conduct in terms of innovation. Our definitions of different kinds of innovation match the OSLO manual recommendations. Product innovation is defined in CIS 2004 and CIS 2008 as the market introduction of a new good or a significantly improved good. ${ }^{7}$ The definition does not change in CIS 2008. Moreover the questionnaire gives a detailed explanation: 'Product innovations (new or improved) must be new to your enterprise, but they do not need to be new to your market.' As far as process innovation is concerned the two CISs report that 'A process innovation is the implementation of a new or significantly improved production process, distribution method, or support activity for your goods or services.' We consider organizational innovation as well. For CIS 2004 an organizational innovation is the implementation of new or significant changes in firm structure or management methods that are intended to improve the firm's use of knowledge. For CIS 2008 'an organizational innovation is a new organizational method in your enterprise's business practices (including knowledge management), workplace organization or external relations that has not been previously used by your enterprise.' The questionnaire added: 'It must be the result of

\footnotetext{
${ }^{6}$ In contrast to the results previously found when authors used patent data, many analyses using CIS data have shown that innovation is persistent at the firm level.

${ }^{7}$ As a result we exclude from our analysis the new services.
} 
strategic decisions taken by management.' These definitions are close but not identical. We mainly focus our analysis on technological innovation as the dependent variable.

All the enterprises included in the target population have 10 employees or more. Industrial and services sectors are included in the core target population. A stratified random sample is drawn from the national business register provided by the National Institute of Statistics in Luxembourg (Statec). The data were collected through face-to-face interviews. Data collection was conducted at the beginning of 2004 for CIS 2004 and at the beginning of 2008 for CIS 2008. We obtained 536 responses for CIS 2004 and 615 responses for CIS 2008. For our study, we constructed a data set composed of the enterprises that answered the two surveys. After merging the responses obtained in the two surveys, our final sample is composed of 243 enterprises. $^{8}$ For the period 2002-2004 the firms with 10 to 49 employees and those with 250 employees and more represent, respectively, $30 \%$ and $21 \%$ of the sample. A great proportion (49\%) of our final sample is composed of firms with 50 to 249 employees. A large majority of firms belong to a group, and $43 \%$ of the firms are active in the industrial sector. We see that $37 \%$ of the firms have in-house research and development activities.

Among the firms present in the sample some of them do not innovate: 121 (49.79\%) in the period 2002-2004 and 132 (54.32\%) in the period 2006-2008. Table 1 gives the number of innovators according to the types of innovation: pure product innovators, pure process innovators, single innovators and complex innovators. We find that $21 \%$ of the firms introduced product innovation only and $11 \%$ introduced process innovation only during the period 2002-2004. An analysis of the combination of these different types of innovation shows that $32 \%$ of the enterprises carried out product or process innovation activities (single innovators) and 18\% carried out both (complex innovators). For the three-year period 20062008 our sample is composed of $25 \%$ single innovators and $21 \%$ complex innovators. The pure product innovators and pure process innovators make up respectively $19 \%$ and $8 \%$. One point deserves particular attention: from the first period to the second only the population of complex innovators rises.

\footnotetext{
${ }^{8}$ Some innovating firms that answered the CIS questionnaire in 2004 do not appear in the next survey (CIS 2008), partly due to economic reasons and partly due to the sampling. It might be that these firms continued to innovate in the next period. As a consequence our study (as with the others we found in the literature) tends to underestimate the scale of innovation persistence.
} 
As far as evolution is concerned it must be pointed out there are 82 persistent innovators (firms innovating in one period only) and 69 sporadic innovators (firms innovating in one period only), knowing that 92 firms do not innovate at all (in the two periods). This means that the scale of innovation persistence is not small since $33.74 \%$ of our sample firms innovate repeatedly. ${ }^{9}$ Among these persistent innovators 23 are complex innovators in the two periods, 30 are single innovators in the two periods and 29 change (single towards complex, or conversely).

Table 1. Populations of innovators

\begin{tabular}{lcccc}
\hline & $\begin{array}{c}\text { Pure product } \\
\text { innovators }\end{array}$ & $\begin{array}{c}\text { Pure process } \\
\text { innovators }\end{array}$ & $\begin{array}{c}\text { Single innovators } \\
\text { (product or } \\
\text { process } \\
\text { innovators) }\end{array}$ & $\begin{array}{c}\text { Complex } \\
\text { innovators } \\
\text { (product and } \\
\text { process } \\
\text { innovators) }\end{array}$ \\
\hline $\mathbf{2 0 0 2 - 2 0 0 4}$ & 52 & 26 & 78 & 44 \\
$\mathbf{2 0 0 6 - 2 0 0 8}$ & $(21.40 \%)$ & $(10.70 \%)$ & $(32.09 \%)$ & $(18.11 \%)$ \\
\hline Source & $(18.87 \%)$ & 19 & 60 & 51 \\
$(7.82 \%)$ & $(24.69 \%)$ & $(20.99 \%)$ \\
\hline
\end{tabular}

Source: Exploitation of CIS 2004 and CIS 2008 in Luxembourg (N=243)

At this stage of our analysis it seems relevant to shed some light on the main characteristics of single and complex innovators. For the period 2002-2004 single innovators differ from complex innovators in terms of size, belonging to a group, organizational innovation and R\&D. Complex innovators are more frequently firms with 250 employees or more (49\%) and firms that belong to a group (78\%). By contrast $56 \%$ of single innovators are firms with 50 to 249 employees and only $60 \%$ of them belong to a group. Complex innovators are also more active in R\&D: $72 \%$ of the complex innovators have in-house R\&D activities (55\% for single innovators). The complex innovators most frequently undertake organizational innovation activities: $76 \%$ of the complex innovators vs. $60 \%$ of the single innovators.

\footnotetext{
${ }^{9}$ For Peters (2009) $89 \%$ of the sample firms were persistent innovators.
} 


\section{Empirical models and variables}

The authors are not unanimous as far as innovation persistence can be measured and accounted for. Two approaches are in competition. The first is labelled in the literature as the Transition Probability Matrix approach. It is used for instance for analysing the survival probabilities among different groups of firms (see among others Cefis and Marsili, 2005). Indeed it is a non-parametric method that does not postulate no specific functional relationship between the variable of interest (here the innovation persistence) and its likely determinants. Cabagnols (2000) used it in the frame of Markov chains for measuring the proportion of firms that remain innovators, knowing that they have innovated in the previous period. This approach is considered as more descriptive that explanative.

Another family of papers uses a probit (or logit) model that sets up the best way to account for innovation persistence (see in particular Clausen et al., 2010; Duflos, 2006; Duguet and Mongeon, 2002; Haned, 2011; Peters, 2009; Raymond et al., 2010). In this vein the aim of the analysis is to answer the question: does success in past innovation activities increase the probability of innovating in the current time period?

The canonical model is the well-known logit model:

$$
\mathrm{y}(\mathrm{t})=\mathrm{a} y(\mathrm{t}-1)+\mathrm{b} \sum \mathrm{b} \cdot \mathrm{x}(\mathrm{t})+\mathrm{u} \quad \text { equation } 1
$$

where y (t) is the probability related to the firm's current decision to innovate, which is a function of its past decision achievement $(\mathrm{y}(\mathrm{t}-1))$ and of some observable firm characteristics from the current period $(x(t))$. The coefficient ' $a$ ' sets up a measure of persistence intensity (the effect of past innovation on the current decision to innovate).

In accordance with the model described by equation 1 we have two groups of independent variables. The first contains the variables matching the firm innovation behaviour in the previous time period (2002-2004). Our data set is rich enough to include different categories of innovation (we will consider this in detail later). The second encompasses the variables delineating the firm characteristics that have a role as drivers of innovation. In the 
evolutionary approach the probability of innovating also depends on a mix of firm-specific characteristics and sectoral configurations (Antonelli, 2008; Cohen, 1995; Dosi, 1997). Because firm economic performance (profitability) is a factor pulling innovation persistence (Cefis, 2003) it would have been very fruitful to obtain indicators measuring firm performance. Unfortunately the data are not available. As a consequence we put into the regressions control variables that we found equally in the recent studies on firm innovation persistence (Clausen et al., 2010; Peters, 2009). Many studies have acknowledged that firm size matters. For instance, large firms have enough resources to invest in knowledge activities (R\&D). We took into account firms' size through three modalities - T1: from 10 to 49 employees, T2: from 50 to 249 employees and T3: more than 249 employees - according to the European definition. We also added two traditional controls: the sector of activity (manufacturing/services, INDUS) and a variable indicating whether the firm belongs to a group (GROUP). We added to the group of regressors the implementation of organizational innovation. Mothe and Nguyen (2011) demonstrated that organizational innovation practices may be a determinant of technological innovation. We retained three categories of organizational practices (OECD, 2005): (a) new business practices for organizing work or procedures, (b) new methods of workplace organization for distributing responsibilities and decision-making (i.e. teamwork, decentralization, integration or de-integration of departments, etc.) and (c) new methods of organizing external relations with other firms or public institutions (i.e. first use of alliances, partnerships, outsourcing, sub-contracting, etc.). These three practices are aggregated into one variable relating to the introduction of one (at least) new or significantly improved organizational practice (INNO_ORG). A firm's capabilities are crucial to its long-term success, as stated in the evolutionary tradition (Nelson and Winter, 1982; Teece and Pisano, 1994). Traditional wisdom considers that R\&D expenditures set up a good proxy for a firm's capabilities. Unfortunately R\&D expenditures are not mentioned in our databases; as a consequence we included the information on whether the firm undertakes (or not) internal R\&D (RRDIN). ${ }^{10}$ To control for competitive intensity, we included the dummy variable (NMARCONC), which takes the value 1 when the competition of the market in which the firm is operating in is very intense - and 0 otherwise. The reader must keep in mind that all these variables are related to the same time period (2006-2008).

\footnotetext{
${ }^{10}$ R\&D expenditures do not always capture all the innovation efforts, especially for small firms (Mohnen and Mairesse, 2010).
} 
Table 2. Variables' definition

\begin{tabular}{|l|l|}
\hline Variables & Description \\
\hline INNO_SINGLE & The firm introduces product or process innovation \\
\hline INNO_COMPLEX & The firm introduces product and process innovation \\
\hline PURE_PDT & Pure product innovator: the firm introduces only new or significantly improved goods \\
\hline PURE_PROC & $\begin{array}{l}\text { Pure process innovator: the firm introduces only new or significantly improved } \\
\text { methods of manufacturing or producing goods or services }\end{array}$ \\
\hline T1 & The total number of employees is between 10 and 49 \\
\hline T2 & The total number of employees is between 50 and 249 \\
\hline T3 & The total number of employees is more than 249 \\
\hline INDUS & The firm belongs to the manufacturing sector \\
\hline GROUP & The firm is part of a group \\
\hline INORG & $\begin{array}{l}\text { Organizational innovation: the firm introduces a new organizational method into its } \\
\text { business practices (including knowledge management), workplace organization or } \\
\text { external relations }\end{array}$ \\
\hline RRDIN & The firm undertakes internal R\&D activity \\
\hline NMARCONC & The competition of the market in which the firms operates is very intense \\
\hline
\end{tabular}

All the variables are dummies

Table 3. Distribution of enterprises by characteristics (means, CIS 2008)

\begin{tabular}{|c|c|c|c|}
\hline & Overall Population & SINGLE Innovator & $\begin{array}{c}\text { COMPLEX } \\
\text { Innovator }\end{array}$ \\
\hline T1 & 0.30041152 & 0.2 & 0.17647059 \\
\hline T2 & 0.48971193 & 0.56666667 & 0.33333333 \\
\hline T3 & 0.20987654 & 0.23333333 & 0.49019608 \\
\hline INDUS & 0.42798354 & 0.51666667 & 0.50980392 \\
\hline GROUP & 0.59259259 & 0.6 & 0.78431373 \\
\hline INNO_ORG08 & 0.55555556 & 0.6 & 0.76470588 \\
\hline RRDIN & 0.3744856 & 0.55 & 0.7254902 \\
\hline NMARCON & 0.47325103 & 0.45 & 0.49019608 \\
\hline Number of observations & 243 & 60 & 51 \\
\hline
\end{tabular}

Table 3 gives the distribution of enterprises according to some characteristics. The main patterns are the following. As far as size is concerned, single innovators differ from complex innovators. The former are more important in the class of medium firms while the latter are in 
the majority larger. They are more numerous for implementing organizational innovation and carrying out R\&D.

Table 4 gives the transition probabilities between different innovation states. We observe that $71.03 \%$ of non-innovators in 2002-2004 remain non-innovators in the later time period. The single innovators in the first period have a larger probability of becoming non-innovators $(38.46 \%)$ than the complex innovators $(22.72 \%)$. From this first point of view, it is clear that complex innovators are more persistent in their innovation strategy. A second trend emerges equally: the probability of remaining a single innovator in the second time period knowing that the firm was a single innovator in the previous period $(38.46 \%)$ is smaller than the probability of staying a complex innovator conditional on having been a complex innovator previously (52.27\%). From this second point of view we find again that complex innovators are more persistent in innovation as well.

Table 4. Transition probability: persistence in activity for single and complex innovators

\begin{tabular}{lcccc}
\hline \multirow{2}{*}{$2002-2004$} & \multicolumn{3}{c}{$2006-2008$} \\
\cline { 2 - 5 } & $\begin{array}{c}\text { Non-innovator } \\
(\%)\end{array}$ & $\begin{array}{c}\text { Single innovator } \\
(\%)\end{array}$ & $\begin{array}{c}\text { Complex innovator } \\
(\%)\end{array}$ & Total \\
\hline Non-innovator $(\%)$ & 71.03 & 15.70 & 8.26 & 121 \\
Single innovator $(\%)$ & 38.46 & 38.46 & 14.88 & 78 \\
Complex innovator $(\%)$ & 22.72 & 25.00 & 52.27 & 44 \\
\hline Total & 132 & 60 & 41 & 243 \\
\hline
\end{tabular}

Source: Exploitation of CIS 2004 and CIS 2008 in Luxembourg ( $\mathrm{N}=243)$

\section{Estimations and results}

Here we follow the second approach of innovation persistence, which states that demonstrating innovation conduct in the past increases the probability of conducting successful innovation activities in the current period. To test this idea we estimate different logit models for single innovators and for complex innovators. Among the regressors we have a 'lagged dependent variable' (a qualitative variable stating that the firm has innovated or not in the past) that sets up a measure of persistence if the coefficient is statistically significantly positive. As regards the 'lagged dependent variable' several specifications are candidates. A good solution is to retain the definition of the independent variable that matches the dependent variable. For instance, if we estimate the probability of being a single (complex) 
innovator in the second period, we put into the right side of the equation the variable of being a single (complex) innovator in the previous period. In order to explore several options and exploit the data better we try other variable specifications. For instance, as far as single innovators are concerned, it is relevant to examine whether the pure product innovator has a higher probability of remaining an innovator in the later period than a pure process innovator. In the same spirit it is fruitful to test whether 'being a single innovator in the previous period' can positively affect the probability of 'being a complex innovator in the current period'.

Table 5 gives the results of the estimations carried out. The first five models are related to the probability of being a single innovator in the current period of time; the last models are related to the probability of being a complex innovator. The set of regressors is the same. The results provide interesting information. First of all there is clearly a process of persistence since the coefficient related to the innovation behaviour in the previous period is positive and significant (models 1 and 2). This means that being a single innovator in the previous time period positively affects the probability of staying a single innovator in the next period. By contrast (model 3), when the firm has been a complex innovator in the previous time period, it impacts negatively (significant at the threshold of 10\%) on the probability of being a single innovator in the current period. Models 4 and 5 confirm that it is product innovation that is important. There is a real difference between product innovators and process innovators. When a firm innovates only in its processes it has no impact in terms of persistence. By contrast the pure product innovator has won the opportunity to remain an innovator (presumably a product innovator). It confirms the idea by Antonelli, Crespi and Scellato (2012): the product innovator has higher persistence intensity. ${ }^{11}$ We turn now to the complex innovator models (models 6 to 10). The important point is the following: being a single innovator in the previous period (whatever the type of innovation: product or process) has no impact on the probability of becoming a complex innovator. By contrast, when the firm has been a complex innovator in the past, it has better (larger) chances to continue along this route. More interestingly the coefficient related to this variable (coefficient a in equation 1) is higher in model 8 than in models 1 and 2. This means that the persistence intensity is higher

\footnotetext{
${ }^{11}$ Parisi et al. (2006) with micro evidence for Italy find the same result. An argument we could put forth to explain this finding is that firm product innovators seem to achieve a higher economic growth rate (see the paper by Colombelli, Haned and Le Bas, 2011). As a consequence they have more resources to invest in R\&D and similar activities.
} 
for complex innovators than for single innovators. The analysis carried out with probability transition is clearly confirmed here.

The regressions give us other insights. Size matters only for the complex innovator dynamic. Large firms have a significant advantage over others as far as innovation persistence is concerned. The dummy for industry (service as the reference) has no significant effect. Another way to take into account sectoral effects consists of the introduction of technological intensity. Raymond et al. (2010) found as a result that there is true persistence in the probability of innovating in the high-tech category of industries and spurious persistence in the low-tech category. In the frame of our study we do not have a large enough sample of firms to undertake some calculations in order to validate this finding. However, some very simple statistical treatments of our data show that low-tech industrial firms are more single innovators than complex (when they innovate). As a consequence, they are less persistent, as demonstrated by our analyses. Our variable organizational innovation has a positive impact on the implementation of innovation. This finding is in line with the paper by Le Bas, Mothe and Nguyen (2011), which found organizational innovation (in particular organizational practices such as knowledge management) to be a determinant factor of innovation persistence in technological innovation. However, in the frame of our model the implementation of organizational innovation has a positive impact but only for increasing the probability of being a complex innovator. We have here a first difference between the determinants of the two types of innovation. Organizational innovation does not play a role for single innovators. The variable RRDIN always has a positive impact on the probability of being single or complex. This finding is well established in the literature (see among others Duguet and Monjon, 2002). However, the coefficient related to this variable is higher for the complex innovators.

\section{Discussions of the findings and conclusion}

We split the sample of 243 firms from Luxembourg according to their innovation behaviour: not an innovator, single innovator (pure product innovator or pure process innovator) or complex innovator (product and process innovator). Estimating the probability to innovate as a function of the innovation strategy previously implemented, we show that complex innovators are more persistent than single innovators. A second finding should deserve equal attention: our results show dissymmetry between the strategy to innovate in products and the 
strategy to innovate in processes. The former seems to have greater strength than the latter to drive the firm on a persistent innovation path. As far as the determinants of innovation persistence are concerned, our results are in line with the previous findings in the literature.

In order to shed light on the factors explaining our main result (the pattern of greater persistence when the firm is a complex innovator) we take over the three explanative frameworks delineated in section 1 . One fundamental characteristic of innovation is that every new innovation consists of new combinations of existing ideas, pieces of knowledge, capabilities and so on. 'Greater the variety of these elements within a system (or an organization) greater the scope for them to be combined in different ways ... Producing new innovations which will be more complex and more sophisticated' (Fagerberg, 2005: 10). This point of view fits well with the analysis of the growth of knowledge by recombination, first systematically described by Weitzman (1996). New knowledge is often produced by recombining scattered existing pieces of knowledge. The basic idea that Weitzman (1996) puts forth is that the expression of human imagination is recombinatoric in essence. This is one reason for which large firms that can manage a lot of recombination projects in the same time period are considered more innovative than small firms, and might be more persistent. This type of analysis tells us that size matters. Large firms enjoy this advantage and as a consequence develop strong learning effects. This fact tends to explain why large firms should be more innovative and presumably more persistent (our results show that large size matters positively to the process of innovation as well) and not that complex innovators per se remain persistent innovators. Nevertheless, we can envisage the same process of recombination 'à la Weitzman' in the frame of complex innovators. In effect being 'complex', the organization works in two directions (products and processes). It has one advantage in terms of the potential for creativity and new ideas in comparison with the firm that is more specialized (product or process). Moreover, it may be there are synergetic relations between improvements to the products and improvements to the processes. The new knowledge generated through the research carried out looking for product improvements can spill over to the research projects aiming to improve processes. Flaig and Stadler (1994) rightly argued that there are some spillover effects from product to process innovations and vice versa. Moreover, it must be pointed out that a large firm has enough resources to work on product and process innovation projects. Firm size and innovation complexity interact positively. The 'success breeds success' hypothesis shows that a complex innovator wins more than a single 
innovator. For instance, Pianta (2005) showed that the strategies of process innovation are associated with price competitiveness, by contrast strategies of product innovation are linked to technological competitiveness (technological leadership). As a consequence the gains of complex innovators are twofold. With the new products (or improved products) they open new markets (taking competitive advantages), and with cost-reducing process innovations they can increase the level of demand for their products. To put it simply, the scale of complex innovators' commercial success enables them to achieve better profitability. Therefore, they can increase the resources devoted to R\&D activity and innovate continuously. Finally, the 'success breeds success' hypothesis tells us that complex innovators have more advantages than single innovators. They are in a virtuous circle. Lastly, the framework suggested by the 'sunk costs in R\&D activities hypothesis' is relevant here: complex innovators that carry out R\&D projects both for product and for process improvements certainly undertake larger $R \& D$ efforts. As a consequence they receive more incentives to stay in a continuing (or persistent) regime of R\&D activity. These general results support the idea that differences across firms in terms of innovation strategy set up a driver of innovation persistence.

The small size of our sample surely sets up the main limitations of our analysis; we can expect further progress by working on a larger sample of firm by incorporating another country. Moreover it may be that 'complex innovator' does not have the same meaning in different industries. As a consequence cross-industry comparisons deserve more attention as one possible extension. The point of view developed here is based on the acknowledgement that firms innovate differently. One way to deal with that is to understand that the sectoral structure matters (which is for instance captured by the trajectories 'à la Pavitt') ${ }^{12}$. Lastly another fruitful future line of research should show whether the two types of innovator are heterogeneous as expected in terms of innovation profitability.

12 Clausen et al. (2010) suggested new lines for making progress in this direction. 
Table 5. Estimation of being single and complex innovators (logit models)

\begin{tabular}{|c|c|c|c|c|c|c|c|c|c|c|}
\hline & \multicolumn{5}{|c|}{ Dependent variable : SINGLE INNOVATOR $(t)$} & \multicolumn{5}{|c|}{ Dependent variable : COMPLEX INNOVATOR $(t)$} \\
\hline & Model 1 & Model 2 & Model 3 & Model 4 & Model 5 & Model 6 & Model 7 & Model 8 & Model 9 & Model 10 \\
\hline $\begin{array}{c}\text { INNO_SINGLE } \\
(\mathrm{t}-1)\end{array}$ & $\begin{array}{c}\mathbf{0 . 8 5 8 0} * * * \\
(0.3339)\end{array}$ & $\begin{array}{c}0.8605^{* * * *} \\
(0.3342)\end{array}$ & I & I & I & $\begin{array}{l}-0.1746 \\
(0.4019) \\
\end{array}$ & $\begin{array}{l}-0.1588 \\
(0.4050)\end{array}$ & I & I & I \\
\hline $\begin{array}{c}\text { INNO_COMPLEX } \\
(\mathrm{t}-1)\end{array}$ & I & I & $\begin{array}{l}-0.7617^{*} \\
(0.4501)\end{array}$ & I & 1 & I & I & $\begin{array}{l}0.9953 * * \\
(0.4396) \\
\end{array}$ & 1 & 1 \\
\hline PURE_PDT (t-1) & 1 & 1 & 1 & $\begin{array}{c}0.7601 * * \\
(0.3685) \\
\end{array}$ & 1 & 1 & 1 & 1 & $\begin{array}{l}-0.3226 \\
(0.4460) \\
\end{array}$ & 1 \\
\hline PURE_PROC (t-1) & I & I & l & 1 & $\begin{array}{c}0.4934 \\
(0.4616) \\
\end{array}$ & I & I & l & I & $\begin{array}{c}0.2353 \\
(0.5764) \\
\end{array}$ \\
\hline $\mathrm{T} 1(\mathrm{t})$ & $\begin{array}{l}-0.6463 \\
(0.4010) \\
\end{array}$ & $\begin{array}{l}-0.6346 \\
(0.4015) \\
\end{array}$ & $\begin{array}{c}-0.6557 * \\
(0.3982) \\
\end{array}$ & $\begin{array}{l}-0.6216 \\
(0.3989) \\
\end{array}$ & $\begin{array}{l}-0.6170 \\
(0.3958) \\
\end{array}$ & $\begin{array}{c}0.2690 \\
(0.4809) \\
\end{array}$ & $\begin{array}{c}0.3035 \\
(0.4856) \\
\end{array}$ & $\begin{array}{c}0.3608 \\
(0.4948) \\
\end{array}$ & $\begin{array}{c}0.3081 \\
(0.4864) \\
\end{array}$ & $\begin{array}{c}0.2997 \\
(0.4852) \\
\end{array}$ \\
\hline $\mathrm{T} 2(\mathrm{t})$ & Ref. & Ref. & Ref. & Ref. & Ref. & Ref. & Ref. & Ref. & Ref. & Ref. \\
\hline T3 (t) & $\begin{array}{l}-0.0222 \\
(0.4185)\end{array}$ & $\begin{array}{l}-0.0543 \\
(0.4233) \\
\end{array}$ & $\begin{array}{l}-0.1557 \\
(0.4158)\end{array}$ & $\begin{array}{l}-0.1219 \\
(0.4178)\end{array}$ & $\begin{array}{l}-0.2329 \\
(0.4119) \\
\end{array}$ & $\begin{array}{c}1.4718 * * * * \\
(0.4320)\end{array}$ & $\begin{array}{c}1.3713 * * * * \\
(0.4387)\end{array}$ & $\begin{array}{c}1.3247 * * * * \\
(0.4424)\end{array}$ & $\begin{array}{c}1.3595 * * * * \\
(0.4358)\end{array}$ & $\begin{array}{c}1.4180 * * * * \\
(0.4336)\end{array}$ \\
\hline INDUS (t) & $\begin{array}{c}0.3605 \\
(0.3308) \\
\end{array}$ & $\begin{array}{c}0.3664 \\
(0.3312)\end{array}$ & $\begin{array}{c}0.4060 \\
(0.3284) \\
\end{array}$ & $\begin{array}{c}0.4054 \\
(0.3299) \\
\end{array}$ & $\begin{array}{l}0.3305 \\
(0.3277) \\
\end{array}$ & $\begin{array}{c}0.4999 \\
(0.3929) \\
\end{array}$ & $\begin{array}{c}0.5614 \\
(0.3991) \\
\end{array}$ & $\begin{array}{c}0.5366 \\
(0.4086) \\
\end{array}$ & $\begin{array}{c}0.5553 \\
(0.3997) \\
\end{array}$ & $\begin{array}{c}0.5450 \\
(0.4000) \\
\end{array}$ \\
\hline GROUP (t) & $\begin{array}{l}-0.3934 \\
(0.3432) \\
\end{array}$ & $\begin{array}{l}-0.4201 \\
(0.3476) \\
\end{array}$ & $\begin{array}{l}-0.3845 \\
(0.3462) \\
\end{array}$ & $\begin{array}{l}-0.4211 \\
(0.3474) \\
\end{array}$ & $\begin{array}{l}-0.3812 \\
(0.3444) \\
\end{array}$ & $\begin{array}{c}0.5424 \\
(0.4185) \\
\end{array}$ & $\begin{array}{c}0.3990 \\
(0.4295) \\
\end{array}$ & $\begin{array}{c}0.3933 \\
(0.4344) \\
\end{array}$ & $\begin{array}{c}0.4095 \\
(0.4301) \\
\end{array}$ & $\begin{array}{c}0.4042 \\
(0.4298) \\
\end{array}$ \\
\hline $\begin{array}{c}\text { INOORG } \\
(\mathrm{t})\end{array}$ & 1 & $\begin{array}{c}0.1698 \\
(0.3333) \\
\end{array}$ & $\begin{array}{c}0.1609 \\
(0.3315) \\
\end{array}$ & $\begin{array}{c}0.1863 \\
(0.3325) \\
\end{array}$ & $\begin{array}{c}0.1482 \\
(0.3300) \\
\end{array}$ & 1 & $\begin{array}{l}0.7059 * \\
(0.4118) \\
\end{array}$ & $\begin{array}{l}.7186 * \\
(0.4155) \\
\end{array}$ & $\begin{array}{l}.6913 * \\
0.4120 \text { ) } \\
\end{array}$ & $\begin{array}{l}0.7030 * \\
(0.4121) \\
\end{array}$ \\
\hline RRDIN (t-1) & $\begin{array}{c}0.7316 * * \\
(0.3504) \\
\end{array}$ & $\begin{array}{l}0.7197 * * \\
(0.3513)\end{array}$ & $\begin{array}{c}1.2290 * * * \\
(0.3624)\end{array}$ & $\begin{array}{l}0.7488 * * \\
(0.3541)\end{array}$ & $\begin{array}{c}0.9847 * * * * \\
(0.3358) \\
\end{array}$ & $\begin{array}{c}1.5686 * * * * \\
(0.4017)\end{array}$ & $\begin{array}{c}1.5294 * * * \\
(0.4057) \\
\end{array}$ & $\begin{array}{c}1.1266 * * * \\
(0.4183)\end{array}$ & $\begin{array}{c}1.5694 * * * \\
(0.4045)\end{array}$ & $\begin{array}{r}1.4695 * * * * \\
(0.3831)\end{array}$ \\
\hline NMARCON (t-1) & $\begin{array}{l}-0.0810 \\
(0.3327) \\
\end{array}$ & $\begin{array}{l}-0.0888 \\
(0.3332) \\
\end{array}$ & $\begin{array}{l}-0.0800 \\
(0.3287) \\
\end{array}$ & $\begin{array}{l}-0.0988 \\
(0.3306) \\
\end{array}$ & $\begin{array}{l}-0.0976 \\
(0.3287) \\
\end{array}$ & $\begin{array}{c}0.0813 \\
(0.3901) \\
\end{array}$ & $\begin{array}{c}0.0581 \\
(0.3939) \\
\end{array}$ & $\begin{array}{c}0.0195 \\
(0.4020) \\
\end{array}$ & $\begin{array}{c}0.0757 \\
(0.3958) \\
\end{array}$ & $\begin{array}{c}0.0608 \\
(0.3948) \\
\end{array}$ \\
\hline Intercept & $\begin{array}{c}-1.4741 * * * \\
(0.4155)\end{array}$ & $\begin{array}{c}-1.5457 * * * \\
(0.4400) \\
\end{array}$ & $\begin{array}{c}-1.3098 * * * \\
(0.4237)\end{array}$ & $\begin{array}{c}-1.4361 * * * * \\
(0.4303)\end{array}$ & $\begin{array}{c}-1.3502 * * * * \\
(0.4253)\end{array}$ & $\begin{array}{c}-3.1783 * * * \\
(0.5753) \\
\end{array}$ & $\begin{array}{c}-3.5172 * * * * \\
(0.6260)\end{array}$ & $\begin{array}{c}-3.5918 * * * \\
(0.6348) \\
\end{array}$ & $\begin{array}{c}-3.5164 * * * \\
(0.6252) \\
\end{array}$ & $\begin{array}{c}-3.5756 * * * \\
(0.6250) \\
\end{array}$ \\
\hline$-2 \log L$ & 249.692 & 249.432 & 253.024 & 251.854 & 254.924 & 198.151 & 195.114 & 190.175 & 194.736 & 195.105 \\
\hline $\begin{array}{l}\text { Percent correctly } \\
\text { predicted }\end{array}$ & 68.8 & 69.1 & 67.2 & 67.2 & 66.2 & 79.9 & 81.3 & 82.8 & 81.3 & 81.3 \\
\hline $\begin{array}{c}\text { Number of } \\
\text { observations }\end{array}$ & 243 & 243 & 243 & 243 & 243 & 243 & 243 & 243 & 243 & 243 \\
\hline
\end{tabular}

Standard error in parentheses. * coef. significant at the threshold of $10 \%, * * 5 \%, * * 1 \%$. Source: Community Innovation Survey. 


\section{References}

Antonelli, C. (2008) Localized Technological Change. Towards the Economics of Complexity. Routledge, London.

Antonelli, C., Crespi, F. and G. Scellato. (2012) Inside innovation persistence: New evidence from Italian micro-data, Structural Change and Economic Dynamics, forthcoming

Cabagnols, A. (2000) Les déterminants des types de comportements innovants et de leur persistance: Analyse évolutionniste et étude économétrique. Phd Université Lyon 2, December 2000.

Cefis, E. (1990) 'Le origini e lo sviluppo di una nuova tecnologia nella produzione di orologi: la Waltham Watch Company', Annali di Storia dell'Impresa, Vol. 5/6 No. 375, pp. 18501883.

Cefis, E. (2003) 'Is there any persistence in innovative activities?', International Journal of Industrial Organization, Vol. 21 No. 4, pp. 489-515.

Cefis, E. and Ciccarelli, M. (2005) 'Profit differentials and innovation', Economics of Innovation and New Technology, Vol. 14 No. 1, pp. 43-61.

Cefis, E. and Marsili, O. (2005) 'A matter of life and death: Innovation and firm survival', Industrial and Corporate Change, Vol. 14 No. 6, pp. 1167-1192.

Cesaratto, S., Mangano, S. and Massini, S. (1995) 'New dimensions on division of labor: The case of Italy (1981-85)', in DeBresson, C. (ed.) Economic Interdependence and Innovative Activity: An Input-Output Analysis, Edward Elgar, Aldershot.

Clausen, T.H., Pohjola, M., Sapprasert, K. and Verspagen, B. (2010) Innovation Strategies as a Source of Persistent Innovation, TIK Working Papers on Innovation Studies No. 20100617.

Cohen, W. (1995) 'Empirical studies of innovative activity', in Stoneman, P. (ed.), Handbook of the Economic of Innovation and Technological Change, Blackwell, Oxford.

Cohen, W. and Levinthal, D. (1989) 'Innovation and learning: The two faces of R\&D', The Economic Journal, Vol. 99, September, pp. 569-596.

Colombelli, A., Haned, N. and Le Bas, C. (2011) On Firm Growth and Innovation: Some new Empirical Perspectives using French CIS (1992-2004), ICER Working Paper No. 7/2011.

Colombelli, A. and von Tunzelmann, N.G. (2011) 'The persistence of innovation and path dependence', in Antonelli, C. (ed.), The Handbook of the System Dynamics of Technological Change, Edward Elgar, Cheltenham.

Dosi, G. (1997) 'Opportunities, incentives and the collective patterns of technological change’, The Economic Journal, Vol. 107 No. 444, pp. 1530-1547. 
Duflos, G. (2006) 'Persistence of innovation, technological change and quality adjusted patents in the US pharmaceutical industry', Cahiers de la MSE, No. 2006-29, 49 pages.

Duguet, E. and Monjon, S. (2002) Creative Destruction and the Innovative Core: Is Innovation Persistent at the Firm Level?, UCL Discussion Paper 02-07.

Fagerberg, J. (2005) 'Innovation: A guide to the literature', in Fagerberg, J., Mowery, D.C. and Nelson, R.R. (eds.), The Oxford Handbook of Innovation, Oxford University Press, pp. 126.

Flaig, G. and Stadler, M. (1994) 'Success breeds success. The dynamics of the innovation process', Empirical Economics, Vol. 19, pp. 55-68.

Geroski, P., Van Reenen, J. and Walters, C.F. (1997) 'How persistently do firms innovate?', Research Policy, Vol. 26, pp. 33-48.

Haned, N. (2011) Firm Performance, Sources and Drivers of Innovation and Sectoral Technological Trajectories. An Empirical Study on Recent French CIS. Thèse de sciences économiques, Université Lumière Lyon 2.

Henderson, R.M. and Cockburn, I.M. (1998) 'Absorptive capacity, coauthoring behavior, and the organization of research in drug discovery', The Journal of Industrial Economics, Vol. 46, pp. 157-182.

Hill, C.W.L. and Rothaermel, F.T. (2003) 'The performance of incumbent firms in the face of radical technological innovation', Academy of Management Review, Vol. 28, pp. 257-274.

Latham, W. and Le Bas, C. (eds.) (2006) The Economics of Persistent Innovation: An Evolutionary View, Springer. Berlin.

Le Bas, C., Cabagnols, A. and Gay, C. (2003) 'An evolutionary view on persistence in innovation: An empirical application of duration models', in Saviotti, P. (ed.), Applied Evolutionary Economics, Edward Elgar.

Le Bas, C., Mothe, C. and Nguyen, U. (2011) 'Technological innovation persistence:

Literature survey and exploration of the role of organizational innovation', CEPS/Instead WP, No.2011_54, 24 p.

Le Bas, C. and Négassi, S. (2002) Les Structures des Activités d'Innovation en France et Comparaison avec Celles des Principaux Partenaires Commerciaux. Final Report, Convention d'Etude Number 19/2000. Commissariat Général Du Plan, Paris, November 2002.

Lhuillery, S. (1994) 'Warum hören Unternehmen auf, innovativ zu sein?', ZEW Wirtschaftsanalysen, Vol. 2 No. 4, pp. 401-414.

Malerba, F. and Orsenigo, L. (1999) 'Technology entry, exit and survival: An empirical analysis of patent data', Research Policy, Vol. 28 No. 6, pp. 643-660. 
Malerba, F., Orsenigo, L. and Peretto, P. (1997) 'Persistence of innovative activities, sectoral patterns of innovation and international technological specialization', International Journal of Industrial Organization, Vol. 15, pp. 801-826.

Mohnen, P. and Mairesse, J. (2010) Using Innovations Surveys for Econometric Analysis, National Bureau of Economic Research, Cambridge, Mass, Working Paper 15857.

Mothe, C. and Nguyen, U. (2011) Non-technological and technological innovations: Do services differ from manufacturing? An empirical analysis of Luxembourg firms, CEPS/Instead Working Paper, No. 2010-01.

Nelson, R.R. and Winter, S.G. (1982) An Evolutionary Theory of Economic Change, Harvard University Press, Cambridge, Mass.

OECD (2005) The Measurement of Scientific and Technological Activities - Proposed Guidelines for Collecting and Interpreting Technological Innovation Data. Paris: OECD Publishing.

Parisi, M.L., Schiantarelli F., Dembelli A.(2006) "Productivity Innovation Creation and Absorption, and R\&D: Micro Evidence for Italy", European Economic Review, 50, 2037 2061.

Pavitt, K., Robson, M. and Townsend, J. (1987) 'The size distribution of innovating firms in the UK: 1945-1983', Journal of Industrial Economics, Vol. 35, pp. 297-316.

Peters, B. (2009) 'Persistence of innovation: Stylized facts and panel data evidence', The Journal of Technology Transfer, Vol. 34, pp. 226-243.

Pianta, M. (2005) 'Innovation and employment', in Fagerberg, J., Mowery, D.C. and Nelson, R.R. (eds.), The Oxford Handbook of Innovation, Oxford University Press.

Polder, M., van Leeuwen, G., Mohnen, P. and Raymond, W., (2009), "Productivity effects of innovation modes," Amsterdam; Statistic Netherlands Working Paper 09033.

Raymond, W., Mohnen, P., Palm, F.C. and Schim Van Der Loeff, S. (2010) 'Persistence of innovation in Dutch manufacturing: Is it spurious?', Review of Economics and Statistics, Vol. 92 No. 3, pp. 495-504.

Roper, S. and Hewitt-Dundas, N. (2008) 'Innovation persistence: Survey and case study evidence,' Research Policy, Vol. 37, pp. 149-162.

Teece, D.J. and Pisano, G. (1994) 'The dynamic capabilities of firms: An introduction', Industrial and Corporate Change, Vol. 3, pp. 537-556.

Weitzman, M.L. (1996) 'Hybridizing growth theory', American Economic Review, Vol. 86, pp. 207-212. 
Wood, E. (1997) SME Innovator Types and their Determinants, ESRC Centre for Business, University of Cambridge, WP No. 72. 